POLLACK PERIODICA

An International Journal for Engineering and Information Sciences

DOI: $10.1556 / 606.2017 .12 .1 .12$

Vol. 12, No. 1, pp. 147-158 (2017)

www.akademiai.com

\title{
CURRENT HEATING ENERGY DEMAND BY THE RESIDENTIAL SECTOR IN CITY PRISHTINA BASED ON THE MAIN RESOURCES
}

\author{
${ }^{1}$ Petrit AHMETI, ${ }^{2}$ Ilir DALIPI, ${ }^{3}$ Agon BASHA, ${ }^{4}$ István KISTELEGDI \\ ${ }^{1}$ Faculty of Architecture and Spatial Planning, University for Business and Technology \\ Kalabria, 10000 Prishtina, Republic of Kosovo, e-mail: petrit.ahmeti@ubt-uni.net \\ ${ }^{2}$ Kosovo Energy Corporation, 15000 Obiliq, Kosovo, e-mail: idalipi@gmail.com \\ ${ }^{3}$ Topo Limited Liability Company, 325 Cedar Street, Suite 1000, Saint Paul \\ MN 55101, e-mail: agonbasha@gmail.com, \\ ${ }^{4}$ Department of Building Constructions and Energy Design, Faculty of Engineering and \\ Information Technology, University of Pécs, Boszorkány út 2, and \\ Energeia Design Building Technology Research Group, Szentágothai Research Centre \\ Ifjúság útja 20, H-7624 Pécs, Hungary, e-mail: kistelegdisoma@mik.pte.hu
}

Received 12 December 2015; accepted 29 August 2016

\begin{abstract}
This paper has the main focus in energy consumption by the residential sector in city of Prishtina. Considering the fact that the energy production in Kosovo is not sufficient in relation with the everyday demand and at the same time the growth of the energy demand based on different resources is evident, a detailed analysis and identification of the energy performance of this sector is inevitable. One of the main components that cause the energy demand in residential sector is the heating energy demand. The energy resource and heating systems used by the residential sector in city of Prishtina are diverse.

This paper elaborates and identifies the number of residential buildings, number of dwellings, building typologies, heating energy resources, heating systems used by the dwellings and the energy demand for heating energy, by using quantitative methodology. Based on the results achieved by the research, future detailed analysis is possible to identify other components, which affect the heating energy demand by the residential sector. These first results can be used as a basis of the first district scaled energy modeling of the city of Pristhina. By applying the energy management method, developed by Prof. Gerhard Hausladen and his research group at the TU München, a first modeling step will be absolved. After analysis of the current state of the investigated districts, future concepts will be made increasing efficiency and sustainability.
\end{abstract}

Keywords: Heating energy, Energy demand, Residential buildings, Urban energy modeling

\section{Introduction}

The growth of the energy demand in general has become a global concern, especially in countries in transition as Balkan's region countries. According to Heating Strategy of Kosovo29 the annual net consumption of energy for space and sanitary 
water heating in the period 2012-2018 will increase in yearly average of ca. 3\% [1] Except the growth of the energy demand in general, also the production of the energy and the resources used for the energy production which have a negative impact on the environment are becoming serious concern in case of Republic of Kosovo.

Production of the electrical energy in Republic of Kosovo is mostly based on fossil fuel, more precisely on coal (lignite) burning, which is a local natural resource. It covers about 95\% (915 MW in 2012) of the overall energy production in Kosovo [2, pp. 12]. Except the fact that it is one of the most non-efficient processes of energy production, coal burning causes pernicious effects on the environment and surrounding. Also according to calculations (in global scale), the coal and petroleum stocks are running out and they can assure the energy necessity of the world till around 60-80 years [3].

A considerable part of energy consumption, electrical, natural resources, district heating etc. comes from the heating energy demand and especially from the residential sector. According to the official anticipation, the residential sector will cover around $37.65 \%$ [2, pp. 24] of the overall energy consumption or in other terms $1 / 3$ of the overall consumption will come from the residential sector, which makes this sector the first consumer of the energy beside industry, transportation, agriculture etc.

Prishtina as a capital of Republic of Kosovo, represent the biggest city in terms of economy, development and specially population growth and migration. Based on official statistical data, Prishtina is the most populated city in Kosovo with 198,689 inhabitants [4]. As a consequence of various problems accumulated, the urban sprawl phenomenon was inevitable. The city not only expanded, but its urban areas actually exceeded city borders and spread to cadastral parcels of neighboring cities [5]. This shows that city of Prishtina is the most representative sample for the research.

Based on the abovementioned and other numerous facts regarding the energy production, resources and energy demand, it is inevitable and urgent to seek for alternative solutions of energy production and reduction of the actual energy consumption. To reduce the actual energy consumption, it is vital to identify the present energy consumption by the residential sector. The process of present energy consumption identification would also be an inducement beside the initiative of 'Codes for Sustainability Assessment of Construction' appliance [6].

This paper analyses and elaborates the residential sector and the heating energy demand based on the local heating energy resources. Based on the findings of this paper it will be possible to hypothesize the actual heating energy consumption by different resources in city Prishtina based on which, it will be possible to compare the situation with other cases in European cities and plan the future solutions in terms of energy consumption.

\section{Material and methods for urban building typology}

About 2365.6 ha or $30.45 \%$ of the land in city of Prishtina is built. About 2011.58 ha out of 2365.6 ha is residential zone, which is mostly dominated by individual dwellings with $23.17 \%$ or 1800 ha and $2.72 \%$ or 211.58 ha of multi-storey residential buildings (Fig. 1). In many municipalities in Kosovo including city of Prishtina in the last 15 years, during the planning process and especially when the need of the urban growth 
boundary and designation of areas for future development are made under the influence of subjective factors, urban boundaries expanded in inappropriate, unsuitable locations often with a high degree of risk [7].

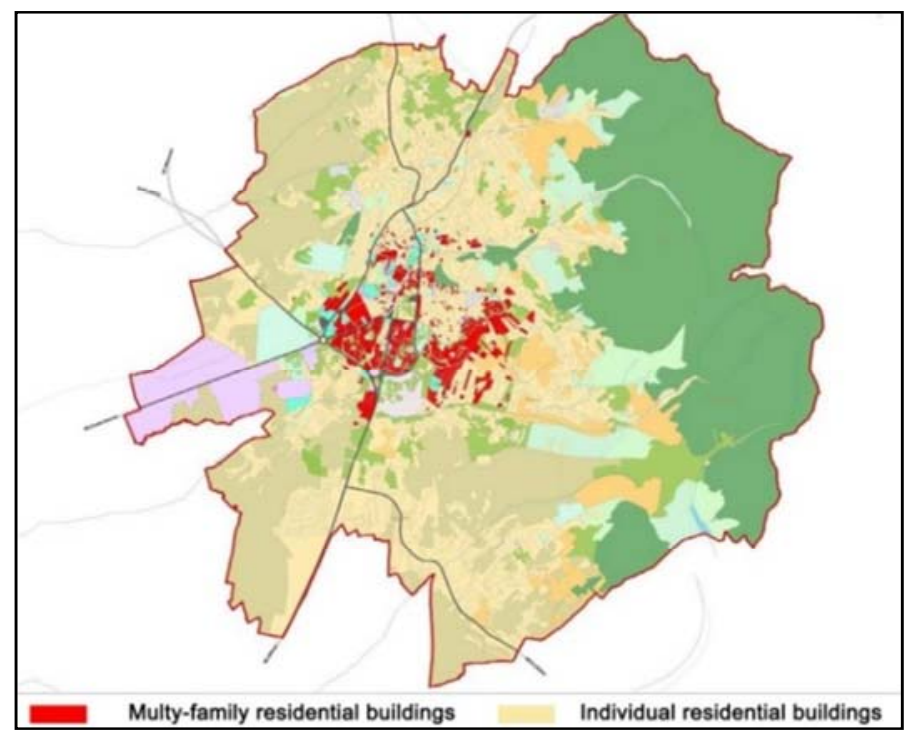

Fig. 1. Actual land use within the urban zone in Prishtina, source Municipality of Prishtina, Urban development plan of Prishtina (source: [8, pp. 72])

Results in Table I show that $85 \%$ of the land is designated for residential buildings. This shows that the largest heating energy consumption comes from the residential sector. In the southern part of the city, big residential areas dominate, for example Dardania and Ulpiana neighborhoods, while the other parts of the city are dominated by the individual mixed houses of the different ranges [9]. Based on this, the research paper treated only the residential sector as the main potential heating energy consumer.

Based on the nature of this research, the methods and the data gathering consist of entirely quantitative and statistical data gathering. To identify and clarify the actual situation of the residential sector in city of Prishtina, it was needed to adopt a very clear methodology, which would help the research to sort out the data, based on building typology, heating energy consumption and heating energy resource.

A settlement scaled, innovative research work was done in Germany, which treated all types of building based on the 'Leitfaden - Energienutzungsplan' ('Guide for energy use plan'), which was written and proposed by Prof. Dr.-Ing. Gerhard Hausladen [10, pp. 5-14]. This Guide for energy use plan fit to this research work perfectly after some method modifications. Particular methodology included a number of steps, whir are divided into 4 main phases.

Two first phases of the 'Guide for energy use plan' where essential for the research, by helping to set of working bases, structuring the urban zones and buildings based on typology, and as a result of the analysis finding the energy demand (Fig. 2). 


\section{Table I}

Destination of the existing areas - source Municipality of Prishtina, Urban development plan of Prishtina (source: [8, pp. 71])

\begin{tabular}{|l|l|c|c|}
\hline $\begin{array}{c}\text { Type of } \\
\text { area }\end{array}$ & \multicolumn{1}{|c|}{ Destination of the existing areas } & $\begin{array}{c}\text { Existing } \\
\text { area } \\
(\mathrm{Ha})\end{array}$ & $\begin{array}{c}\text { Existing } \\
\text { area } \\
(\%)\end{array}$ \\
\hline Built \\
area & Multi-storey residential building & 211.58 & $2.72 \%$ \\
& Individual dwelling & 1800 & $23.17 \%$ \\
& Kindergarten & 4.23 & $0.05 \%$ \\
& Educative building & 30.47 & $0.39 \%$ \\
& Healthcare building & 33.9 & $0.44 \%$ \\
& Administrative & 50.08 & $0.64 \%$ \\
& Economic zone & 217.94 & $2.81 \%$ \\
& Hotel & 0.81 & $0.01 \%$ \\
& Bank & 0.88 & $0.01 \%$ \\
& Library & 0.89 & $0.01 \%$ \\
& Church & 4.39 & $0.06 \%$ \\
& Mosque & 2.74 & $0.04 \%$ \\
& Police & 1.45 & $0.02 \%$ \\
& Post office & 1.77 & $0.02 \%$ \\
& Dormitory & 4.47 & $0.06 \%$ \\
\hline
\end{tabular}

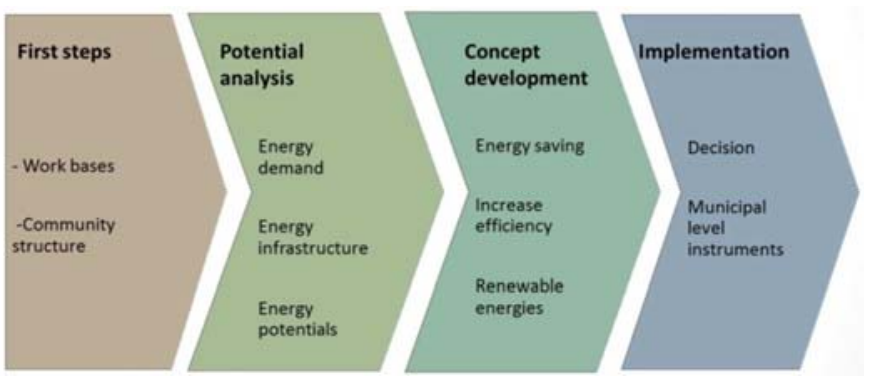

Fig. 2. Phases in the creation of an energy use plan, (source: the Author's plot on the basis of ‘Leitfaden Energienutzungsplan' [10, pp. 5, Fig. 1.1])

First and second step were accomplished using all relevant data gathered by the institutions and respective companies. These data included city's maps, statistical data, urban plans, urban development plans, etc. With these data, settlement structuring could be by identifying residential zones, building typologies and residential zones based on different building typologies.

Firstly, the urban integral zones of the city of Prishtina were identified (Fig. 3) [8]:

- North Prishtina 'The hill';

- West Prishtina 'Arbëria';

- South Prishtina 'Kalabria';

- New Prishtina;

- Center; 
- East Prishtina 'Shore';

- 'Gërmia' forest.

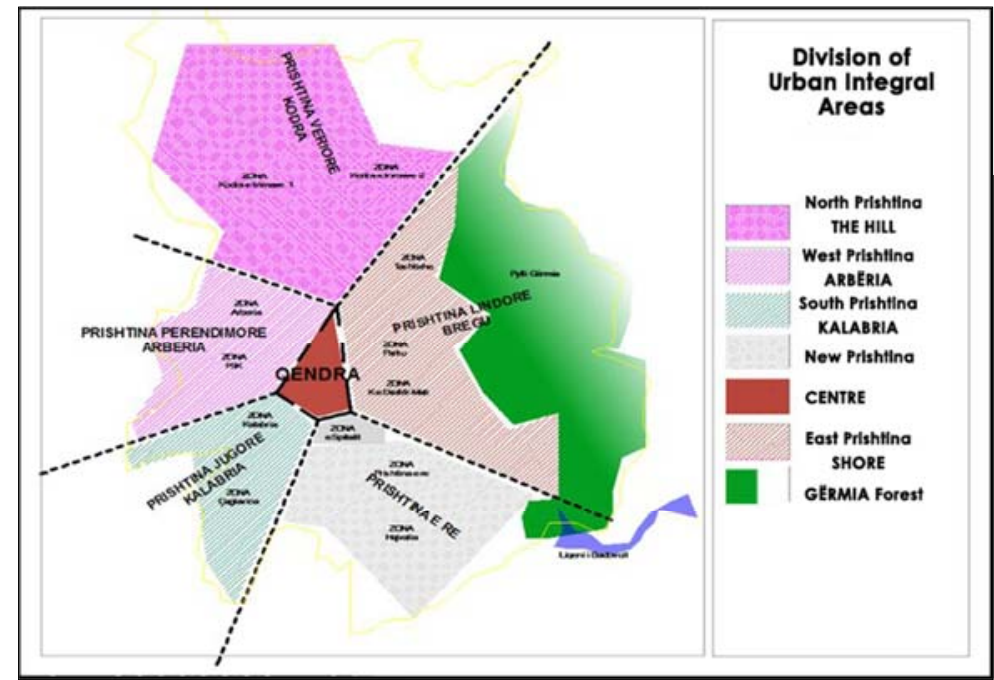

Fig. 3. Division of Urban Integral Areas of Prishtina, source: Urban Development Plan of Prishtina (source: [8, pp. 194])

After identifying the main integral zones, the main neighborhoods could be identified within these zones. Identifying the main neighborhoods was vital for this phase of the research because it facilitated the identification of residential zones within the city of Prishtina in general (Fig. 4). This eased the work for identifying residential zones based on building typologies.

In parallel with collection of the visual data in form of maps, plans, also statistical data was gathered. The combination of these two data types clarified in details the actual situation of city of Prishtina in terms of residential building spreading, typologies, number of buildings and dwellings.

Essential for this phase of particular research was the determination of the exact number of residential buildings and dwellings.

Based on the statistical data, it is evident that over $80 \%$ of dwellings are situated in urban zone of Prishtina Municipality (Table II, Fig. 5). This result served as the basis for focusing the investigation only in urban area, because the result will represent over $80 \%$ of the residential sector of the Prishtina Municipality. Also based on residential building typology, the urban zone was represented by more than $70 \%$ in each typology (Table III, Fig. 6).

In this phase, after gathering and structuring the data for number of building/dwellings and building typologies method of building typology grouping (Fig. 7) is needed to modify, because this research had the focus only in residential sector and not in all building types. So the graphic of typology grouping was adopted. 


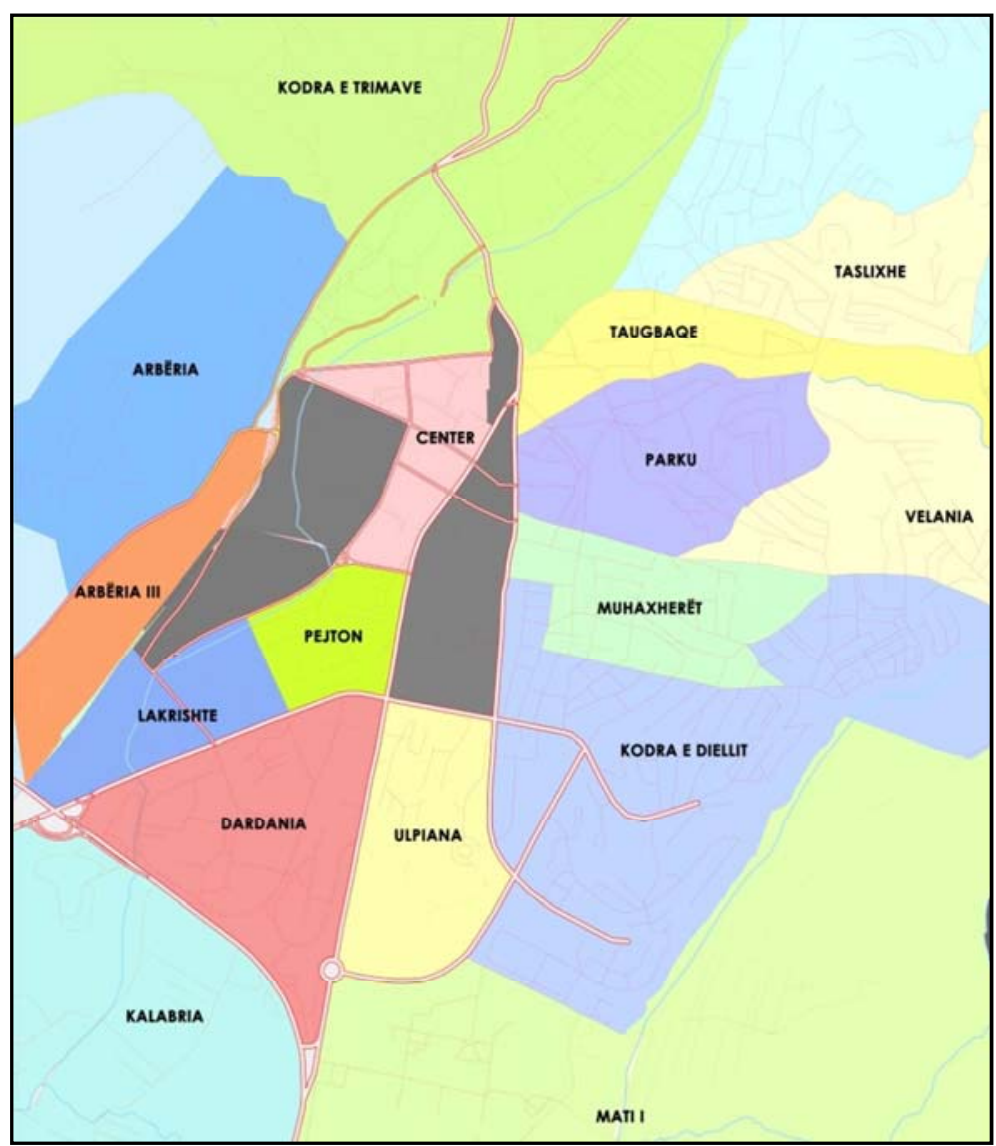

Fig. 4. Neighborhoods within urban area of Prishtina

(source: the Author's plot on the basis of statistical data from Urban development plan of Prishtina 2012-2022, Municipality of Prishtina [8], Households based on municipalities, Registration of the population and dwelling in Kosovo [4, pp 72])

Table II

Dwelling- Types and way of utilization in Municipality of Prishtina, number of flats [4, pp. 12]

\begin{tabular}{|l|c|c|c|c|c|c|c|}
\hline \multirow{2}{*}{$\begin{array}{c}\text { Type of } \\
\text { dwelling }\end{array}$} & Total & $\begin{array}{c}\text { Other types } \\
\text { (lightweight } \\
\text { or mobile } \\
\text { structures) }\end{array}$ & Total & $\begin{array}{c}\text { Conventional dwelling (masonry, concrete structures) } \\
\text { for one } \\
\text { or } \\
\text { more } \\
\text { inhabit. }\end{array}$ & $\begin{array}{c}\text { Used } \\
\text { by the } \\
\text { foreign } \\
\text { inhabit. }\end{array}$ & $\begin{array}{c}\text { Used for } \\
\text { secondary } \\
\text { needs }\end{array}$ & Uninhabited \\
\hline Urban & 49462 & 32 & 49430 & 33651 & 617 & 3140 & 12022 \\
Rural & 9958 & 43 & 9915 & 6325 & 31 & 179 & 3380 \\
Prishtina & 59420 & 75 & 59345 & 39976 & 648 & 3319 & 15402 \\
\hline
\end{tabular}




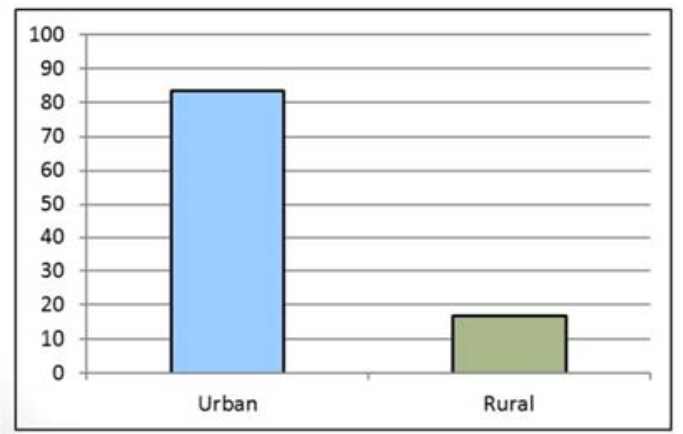

Fig. 5. Chart of residential buildings spreading in urban and rural zones of Prishtina Municipality (source: the Author's chart on bases of Table II)

\section{Table III}

Types of residential buildings in Municipality of Prishtina, source Kosovo Agency of Statistics (source: [4, pp. 75])

\begin{tabular}{|c|c|c|c|c|c|c|}
\hline & \multicolumn{6}{|c|}{ Type of building } \\
\cline { 2 - 7 } & Total & $\begin{array}{c}\text { Single } \\
\text { detached } \\
\text { house }\end{array}$ & $\begin{array}{c}\text { Semi- } \\
\text { detached } \\
\text { house }\end{array}$ & $\begin{array}{c}\text { Terraced } \\
\text { house }\end{array}$ & $\begin{array}{c}\text { Multi-story or } \\
\text { block of } \\
\text { apartments }\end{array}$ & Other \\
\hline Urban & 17543 & 14685 & 1593 & 235 & 964 & 66 \\
\hline Rural & 6063 & 5840 & 146 & 59 & 13 & 5 \\
\hline Prishtina & 23606 & 20525 & 1739 & 294 & 977 & 71 \\
\hline
\end{tabular}

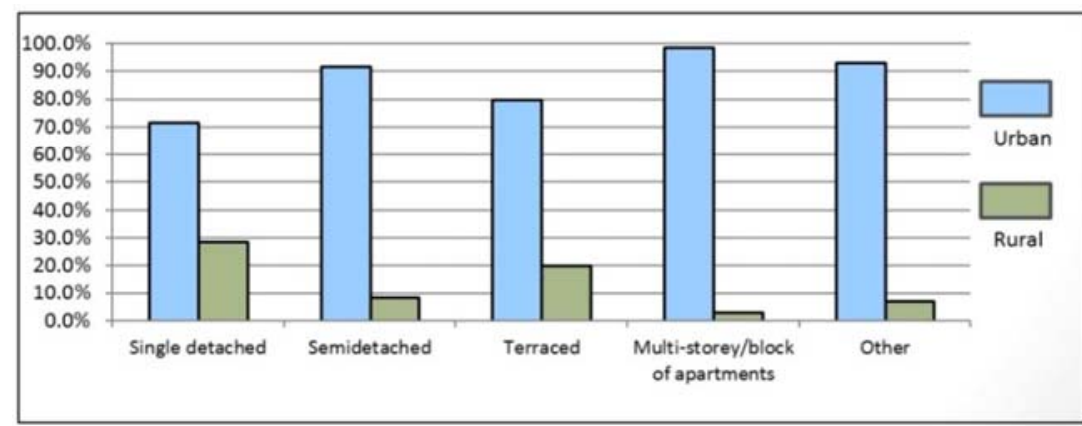

Fig. 6. Chart of residential buildings spreading in urban and rural zones of Prishtina Municipality, based on typology

So the building types were grouped in 3 main topology groups based on building rise- low, medium and high; and sub grouping based on year of construction. The classification is similar to the national classification method known as 'Building type matrix' by Tabula [11]. Based on this methodology, it was very easy to identify the buildings throughout urban zone of Prishtina (Table IV). 
Based on the typology grouping, it was possible to create a map of residential building spread based on building typology. Compared to Prof. Dr Hausladen's methodology (Fig. 7) based on which the buildings are grouped as Residential and Nonresidential, in this research only residential buildings were a subject of the study, so the methodology was modified to correspond to the subject of the research (Fig. 7).

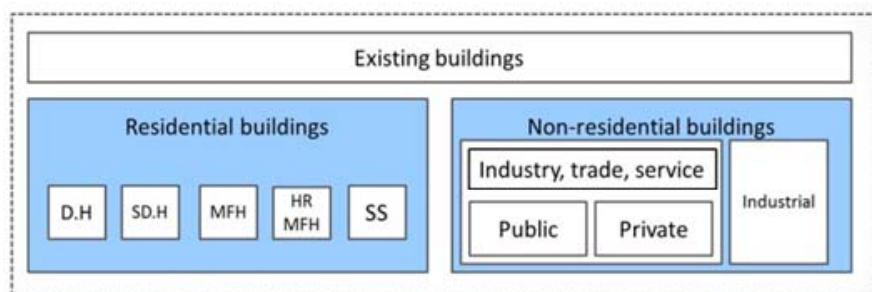

a)
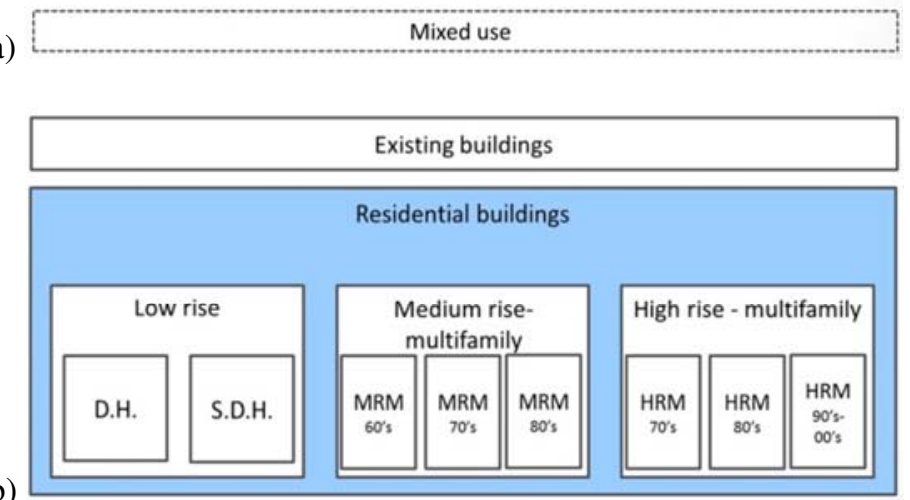

Fig. 7. a) Existing buildings grouping based on use and type, (source: Author's plot on the basis of 'Leitfaden Energienutzungsplan' [10 pp. 11, Fig. 2.2]), b) Modified only for residential buildings (D.H - Detached houses; SD.H - Semi-detached Houses; MFH-Multy-Family House; HR MFH - High-rise Multy-Family House; SS - Skyscraper; MRM - Medium-rise Multy-Family; HRM - High-rise Multy-Family)

\section{Table IV}

Number of residential buildings based on typology in city of Prishtina, (source: Kosovo Agency of Statistics [4])

\begin{tabular}{|c|c|}
\hline \multicolumn{2}{|c|}{ Residential building typology } \\
\hline Total & 23606 \\
$1-3$ storey & 21945 \\
$4-5$ storey & 1198 \\
$6-16+$ storey & 463 \\
\hline
\end{tabular}

It is very common for every city to have administrative division zones (neighborhoods) with homogenous residential building typologies and also heterogeneous or mixed residential building typologies. In Prishtina's case there are 
homogenous and heterogeneous residential building zones in terms of building typologies, so the idea of this research was to create a map of zones based on residential building typologies after analyzing and identifying the zones within the administrative division zones (neighborhoods). After the creation of residential building typology zones, it was possible to identify the spreading of different residential building types within the urban zone of Prishtina and creates a map of residential building spread based on typology (Fig. 8).

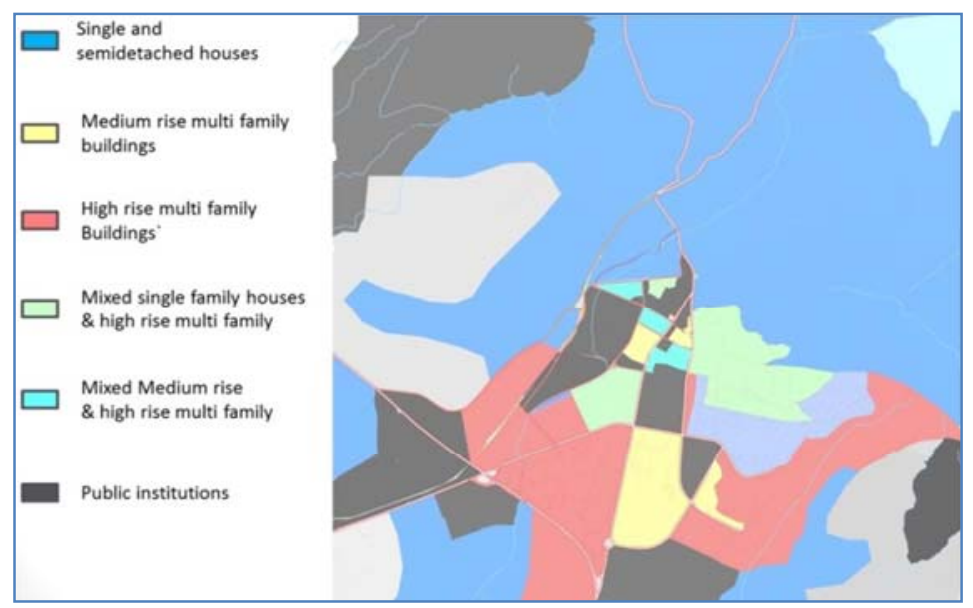

Fig. 8. Map of residential buildings spread throughout urban area of Prishtina, based on building typology (source: Author's plot on the basis of statistical data from Urban development plan of Prishtina 2012-2022, Municipality of Prishtina [8], Households based on municipalities, Registration of the population and dwelling in Kosovo [4, pp 72])

\section{Energy calculations based on statistical data}

Meanwhile it was possible to collect appropriate quality and quantity of data for residential buildings and dwellings, heating resource used by dwellings, structuring the data and categorizing all the information into tables and graphs. The main subject of the research was to use all available data, based on which it was possible to hypothesize the actual energy consumption for heating the residential buildings, in measurable unit. So at this point it was essential to identify the energy consumption in measurable unit, of one of the resources, so it was possible to calculate the consumption for each heating resource presented in the Table $V$ and as a result the sum of all heating resources, which would represent the total consumption.

Based on the findings by the study of Energy Sector Technical Assistance Project (ESTAP)/World Bank, the average heating load of dwellings, which are supplied with heating by the district heating, varies between $150-200 \mathrm{kWh} / \mathrm{m}^{2} \mathrm{a}[8, \mathrm{pp} .172-173]$. The heated area by the district heating was identified by the Municipality of Prishtina, according to which there are $698682 \mathrm{~m}^{2}$ of heated area only in residential sector [8, pp. 93]. For each square meter the demand appeared to be $200 \mathrm{kWh} / \mathrm{m}^{2} \mathrm{a}$ 
[8, pp. 172-173]. Implementing a simplified calculation from which the total consumption may derive the hypothesized heating energy demand by residential sector in city of Prishtina. In this calculation it was essential to have the total heated area of the residential sector, which is connected and heated by the district heating. Based on the calculation it was presumable to find the final energy consumption of $127198.8 \mathrm{MWh} / \mathrm{m}^{2}$ a (Table VI). This value represents the approximate demand for heating energy by the residential sector, which is connected to the district heating system. So if the district heating provides heating approximately $17 \%$ of the residential sector of city of Prishtina [8, pp. 93], than it was simple to find the total energy demand for heating (Table $\mathrm{V}$ ).

\section{Table $V$}

Type of resource used for heating, by dwellings in city of Prishtina (source: Kosovo Agency of Statistics [4, pp. 40-43])

\begin{tabular}{|c|c|c|c|c|c|c|}
\hline & Overall & $\begin{array}{c}\text { District } \\
\text { heating }\end{array}$ & Electricity & $\begin{array}{c}\text { Wooden } \\
\text { products }\end{array}$ & Coal & Other \\
\hline $\begin{array}{c}\text { Number of } \\
\text { dwellings/households }\end{array}$ & 39915 & 6774 & 7697 & 23262 & 1220 & 962 \\
$\begin{array}{c}\text { Heated floor space of } \\
\text { dwellings/households } \\
{\left[\mathrm{m}^{2}\right]}\end{array}$ & 4117160 & 698 & 793788.4 & 2399481 & 125985.1 & 99223.55 \\
$\begin{array}{c}\text { Percentage of } \\
\text { dwellings using } \\
\text { different heating } \\
\text { resource \% }\end{array}$ & 100 & 16.97 & 19.28 & 58.28 & 3.06 & 2.41 \\
\hline
\end{tabular}

According to Table VI, which is created based on the data gathered from the Kosovo Statistical Agency [4, pp. 43] there are 6774 households or $17 \%$ of households that are supplied with heating by the District heating, which in comparison with region is not satisfactory, - for example in comparison to Skopje/Macedonia (44 163 households), meaning $32.15 \%$ are supplied with heating by district heating [12].

Table VI

Type of resource used for heating, by dwellings in city of Prishtina (source: Kosovo Agency of Statistics [4])

\begin{tabular}{|c|c|c|c|c|c|c|}
\hline & Overall & $\begin{array}{c}\text { District } \\
\text { heating }\end{array}$ & Electricity & $\begin{array}{c}\text { Wooden } \\
\text { products }\end{array}$ & Coal & Other \\
\hline $\begin{array}{c}\text { Percentage of } \\
\text { dwellings } \\
\text { using different } \\
\text { heating } \\
\text { resource \% }\end{array}$ & 100 & 16.97 & 19.28 & 58.28 & 3.06 & 2.41 \\
\hline $\begin{array}{c}\text { Hypothesised } \\
\text { consumption } \\
\text { of energy } \\
\text { MWh/a }\end{array}$ & 749551 & 127198.8 & 144513.4 & 436838.3 & 22936.26 & 18064.18 \\
\hline
\end{tabular}


The accuracy of the result was confirmed by calculating the total consumption, number of heated dwellings (39 915 dwellings) [4, pp. 40-43] and the average area of a common dwelling, so:

$$
E_{d w e l l i n g}=\frac{E_{\text {total }}}{n_{d w e l l i n g}}
$$

whereby $E_{d w e l l i n g}$ consumption/dwelling [MWh/dwelling a]; $E_{\text {total means total }}$ consumption of heated dwellings [MWh/m² a]. So $E_{d w e l l i n g}$ is $749551 \mathrm{MWh} / \mathrm{m}^{2} \mathrm{a} / 39915$ number of dwellings $=18.77 \mathrm{MWh} /$ dwellin a. That means calculated with approximated $80 \mathrm{~m}^{2}$ common dwelling net floor space $234.7 \mathrm{kWh} / \mathrm{m}^{2}$ a specified energy consumption.

The heating demand of $234.7 \mathrm{kWh} / \mathrm{m}^{2}$ a for a dwelling and particularly for single detached houses represents a very reliable value, based on the current building quality in Kosovo. This result provides us with confidence that the calculations and final result are comparable with the reality of the current energy consumption situation. For example in comparison with Hungarian current conventional buildings energy consumption, which varies between $260-300 \mathrm{kWh} / \mathrm{m}^{2}$ a [13], the level of Kosovo's current conventional hypothesized consumption is comparatively realistic. In comparison with low energy houses, which use less than $30 \mathrm{kWh} / \mathrm{m}^{2} \mathrm{a}$ [14, pp. 70] the heating energy consumption is $87.2 \%$ higher, furthermore passive-house use less than $15 \mathrm{kWh} / \mathrm{m}^{2} \mathrm{a}$ [15], compared to which the actual consumption of a dwelling is $92.5 \%$ higher in city of Prishtina.

\section{Conclusion}

The heating load of dwellings in city of Prishtina results to be high in comparison with EU standards and specific building quality standards as passive-house and low energy house. As a result, the heating demand by the residential sector in city of Prishtina remains high and also the resources used for the heating remain to be nonefficient, destructive for nature and the environment.

The research results could help future research works to clarify and calculate more precise energy demand for heating by the dwellings categorized in typology, year of construction.

\section{Acknowledgements}

A great contributor on this research work was given by the Department of Urbanism in Municipality of Prishtina, Kosovo Statistical Agency, Alban Beha from District Heating of Prishtina 'Termokos', Ahmet Mujeci from Kosovo Electrical Corporation. This work has also been supported by Prof. Dr. Habil. István Kistelegdi, DLA, PhD, head of Energia Design Building Technology Research Group, Szentágothai Research Center, and Department of Building Constructions and Energy Design, Faculty of Engineering and Information Technology, University of Pécs. 


\section{References}

[1] Sahiti N. National background report on energy for Kosovo, Co-ordination of Research Policies with the Western Balkan Countries, 2012.

[2] Ministry of Economic Development, Energy Strategy of the Republic of Kosovo, Prishtina, Republic of Kosovo, 2013.

[3] Tóth N., Szemes P. T. Investigation of the energy poverty risk with building mechatronics, International Review of Applied Sciences and Engineering, Vol. 4, No. 2, 2013, pp. $177-184$.

[4] Kosovo Agency of Statistics, Households based on municipalities, Registration of the population and dwelling in Kosovo, (in Albanian) 2011.

[5] Mejzini I. The phenomena of urban sprawl, study case of city of Prishtina, (Ed.) Edmond Hajrizi, Book of Proceedings of 4th UBT Annual International Conference on Business, Technology and Innovation, Durres, Albania, 6-7 November 2015, pp. 34-40, http://conferences.ubt-uni.net/digital-proceedings/books/Architecture $\% 20$ and $\% 20$ Spatial\%20Planning\%20Civil\%20Engineering,\%20Infrastructure\%20and\%20Environment.p df, (last visited 15 December 2015).

[6] Nushi V. Role of codes for sustainability assessment of constructions, Proceedings of the International Conference Sustainability of Constructions Towards a Better Built Environment, Final Conference of the COST Action C2, Innsbruck, Austria, 3-5 February 2011, pp. 175-182.

[7] Murseli R., Isufi F. Land suitability location analysis for housing development using GIS, Book of Proceedings of 3rd UBT Annual International Conference on Business, Technology and Innovation, (Ed.) Edmond Hajrizi, Durres, Albania, 7-8 November, 2014, http://conferences.ubt-uni.net/digital-proceedings/books/Computer $\% 20$ Science $\% 20$ and $\%$ 20Communication \%20Engineering\%20Information\%20Systems $\% 20$ and $\% 20$ Security.pdf (last visited 10 December 2015).

[8] Municipality of Prishtina, Urban development plan of Prishtina 2012-2022, (in Albanian) 2013.

[9] Jakupi A. The effect of the International Community Presence in the urban development of post conflict city, Case study, Kosova, Lap Lambert, Academic Publishing, 2013.

[10] Hausladen G, Hamacher T. Leitfaden Energienutzungsplan, Bavarian State Ministry of Environmental Health, 2011.

[11] Vimmr T., Loga T., Diefenbach N., Stein B., Bachová L. Tabula-residential building typologies in 12 European countries, good practice example from the Czech Republic, Central European Towards Sustainable Building 2013, Decision-support tools and assessment methods, 2013, pp. 1-5.

[12] Brajkovski B, Ramadani M. Energy regulatory commission of the Republic of Macedonia, Partnership program, Vermont, Republic of Macedonia, May 23-27, 2005.

[13] Horn V. Balcony structures, Pollack Periodica, Vol. 6, No. 2, 2011, pp. 115-130.

[14] International Energy Agency, Energy efficiency requirements in building codes, Energy efficiency policies for new buildings, 2008.

[15] Crawford R. H., Stephan A. The significance of embodied energy in certified passive houses, International Journal of Civil, Environmental, Structural, Construction and Architectural Engineering, Vol. 7, No. 6, 2013, http://waset.org/publications/ 7209/the-significance-ofembodied-energy-in-certified-passive-houses, (last visited 15 December 2015). 